\title{
PENERAPAN METODE PEMBELAJARAN EDUTAINMENT PADA PEMBELAJARAN PSYCHROMETRIC UNTUK MENINGKATKAN HASIL BELAJAR SISWA SMK
}

\author{
Asep Zakaria ${ }^{1}$, Kamin Sumardi ${ }^{2}$, Ega T. Berman ${ }^{3}$ \\ Universitas Pendidikan Indonesia \\ J1. Dr. Setiabudhi No. 229 Bandung 40154 \\ asep.zakaria@student.upi.edu
}

\begin{abstract}
ABSTRAK
Penelitian ini bertujuan untuk mengetahui peningkatan hasil belajar dan aktivitas belajar siswa setelah menggunakan metode pembelajaran edutainment pada pembelajaran psychrometric. Metode penelitian yang digunakan adalah Penelitian Tindakan Kelas. Penelitian ini terdiri atas tiga siklus. Setiap siklus terdiri atas kegiatan perencanaan, pelaksanaan tindakan, observasi dan refleksi. Teknik pengumpulan datanya menggunakan soal pretest, posttest dan observasi. Hasil penelitian menunjukkan terjadi peningkatan hasil belajar siswa yang ditunjukkan oleh nilai rata-rata hasil belajar siswa pada siklus I adalah sebesar 74,4, pada siklus II sebesar 81,1 , dan pada siklus III sebesar 85 dengan nilai rata-rata $N$-Gain siklus I adalah sebesar 0,6 , siklus II sebesar 0,6 , dan siklus III sebesar 0,7. Penerapan metode pembelajaran edutainment juga menyebabkan aktivitas belajar siswa meningkat pada setiap siklusnya. Hasil rata-rata persentase aktivitas belajar pada siklus I adalah sebesar $39,8 \%$, siklus II sebesar $65,2 \%$, dan siklus III sebesar $84,2 \%$. Kesimpulan dari penelitian ini bahwa dengan menerapkan metode pembelajaran edutainment dapat meningkatkan hasil belajar dan aktivitas belajar siswa pada pembelajaran psychrometric.
\end{abstract}

Kata kunci: edutainment, psychrometric, aktivitas belajar, hasil belajar.

\section{PENDAHULUAN}

Mata pelajaran yang ada di program keahlian Teknik Pendingin dan Tata Udara di kelas XI salah satunya adalah Sistem dan Instalasi Tata Udara. Materi pembelajaran yang ada dalam mata pelajaran ini adalah Psychrometric. Setiap siwa harus menguasai konsep dari materi ini guna menunjang keterampilan dalam prakteknya. Pembelajaran ini bertujuan agar para siswa mampu mengetahui karakteristik udara baik sifat secara fisik maupun sifat termodinamikanya. Selain itu, materi pembelajaran ini akan membantu para siswa untuk mempermudah ketika melakukan suatu perencanaan tata udara. Namun, pada kenyataannya, tidak semua siswa kelas ini bisa menguasainya secara menyeluruh. Siswa mengalami kebingungan ketika mempelajarinya.

Masih belum seimbangannya kemampuan praktik dengan kemampuan penguasaan materi para siswa. Para siswa mengalami kesulitan untuk menjelaskan apa yang di

\footnotetext{
${ }^{1}$ Mahasiswa Departemen Pendidikan Teknik Mesin FPTK, UPI

${ }^{2}$ Dosen Departemen Pendidikan Teknik Mesin FPTK, UPI

${ }^{3}$ Dosen Departemen Pendidikan Teknik Mesin FPTK, UPI
} 
praktekannya. Selain itu, ketika proses pembelajaran berlangsung para siswa masih belum terlibat secara aktif. Kondisi seperti ini mengharuskan kita untuk memberikan perhatian yang serius guna meningkatkan kemampuan para siswa dalam menguasai konsep atau materi pada pembelajaran tersebut (Hanafiah dan Suhana, 2009). Bahkan tidak jarang ketika proses pembelajaran berlangsung, masih ada siswa yang asik dengan dunianya sendiri seperti menggunakan handphone, berbicara dengan teman sebangkunya dan aktivitas-aktivitas lainnya yang tidak ada kaitannya dengan pembelajaran.

Sehingga diperlukan metode pembelajaran yang inovatif agar para siswa bisa terlibat aktif dan bersemangat dalam mengikuti proses pembelajaran. Siswa yang terlibat aktif dalam pembelajaran dapat membantu dalam menguasai suatu mata pelajaran (Dimyati dan Mudjiono, 2006). Agar para siswa merasa senang dan terlibat aktif dalam proses pembelajaran, maka solusi yang ditawarkan adalah dengan menggunakan metode pembelajaran edutainment. Metode ini diharapkan agar para siswa bisa menikmati proses pembelajaran.

Beberapa masalah yang harus dijawab melalui penelitian ini antara lain: bagaimanakah hasil belajar siswa setelah menggunakan metode pembelajaran edutainment pada pembelajaran psychrometric? dan apakah terjadi peningkatan aktivitas belajar siswa setelah menggunakan metode edutainment pada pembelajaran psychrometric? Tujuan penelitian ini adalah untuk memperoleh peningkatan hasil belajar dan aktivitas belajar siswa setelah menggunakan metode pembelajaran edutainment pada pembelajaran psychrometric.

Secara teoritis, penelitian ini dapat memberikan sumbangan mengenai metode pembelajaran edutainment bagi ilmu pengetahuan dan khususnya bagi dunia pendidikan untuk meningkatkan pembelajaran psychrometric. Manfaat praktis yang diharapkan dapat membantu siswa dalam memahami materi pembelajaran dan menjadi salah satu pilihan metode bagi guru sebagai upaya dalam menerapkan metode pembelajaran yang variatif dan inovatif.

\section{METODE PENELITIAN}

Metode penelitian yang digunakan dalam penelitian ini adalah Penelitian Tindakan Kelas (PTK). Metode ini digunakan dalam rangka memecahkan permasalahan yang terjadi di dalam kelas ketika proses pembelajaran berlangsung. PTK adalah penelitian yang dilakukan oleh guru di kelasnya sendiri melalui refleksi diri dengan tujuan untuk memperbaiki kinerjanya, sehingga hasil belajar siswa meningkat. Adapun tahapan-tahapan 
PTK yang dipilih adalah model Lewin. Model ini dipilih karena lebih mudah untuk diaplikasikan dalam proses pembelajaran.

Tahapan-tahapan dalam melaksanakan PTK model ini merupakan satu daur ulang atau siklus yang terdiri dari merencanakan perbaikan, melaksanakan tindakan, mengamati, dan melakukan refleksi. Instrumen penelitian yang digunakan peneliti adalah pretest, posttest, dan observasi. Pretest merupakan tes kemampuan awal siswa sebelum dilakukan proses pembelajaran dengan metode edutainment. Posttest diberikan kepada siswa setelah siswa melakukan proses pembelajaran dengan metode edutainment. Observasi dilakukan dengan mengamati kegiatan guru dan aktivitas siswa selama pembelajaran berlangsung. Lembar observasi guru dan siswa diisi oleh observer.

Teknik pengolahan datanya adalah dengan menilai hasil belajar siswa pada aspek kognitif dan afektif siswa. Peningkatan hasil belajar siswa pada aspek kognitif dapat dilihat dari data yang diperoleh peneliti berdasarkan hasil tes yang telah dilakukan, berupa pre test dan post test. Hasil dari tes tersebut diolah dan didata dengan rapi. Kemudian, data hasil pengolahannya diinterpretasikan dan dilihat peningkatan siswa yang tuntas dalam belajarnya. Sesuai dengan kurikulum yang ditetapkan di SMKN 1 Cimahi bahwa dalam pembelajaran mata pelajaran produktif dalam hal ini Sistem dan Instalasi Tata Udara bahwa siswa dikatakan lulus jika mendapat nilai Kriteria Ketuntasan Minimum (KKM) $\geq$ 75. Sedangkan, untuk menilai afektif siswa adalah dengan melakukan observasi aktivitas belajar siswa yang mengacu pada indikator penialaian pada aspek membaca, mencatat, bertanya, menjawab, presentasi, mendengar, partisipasi, dan antusiasme siswa.

\section{HASIL PENELITIAN}

Hasil belajar siswa dengan menggunakan metode pembelajaran edutainment ini meliputi nilai rata-rata pretest dan nilai rata-rata posttest. Nilai rata-rata siswa yang didapat para siswa pada siklus I, II, dan III. Kemampuan siswa dalam menguasai konsep psychrometric dan psychrometric chart bisa dilihat dari hasil tes awal yang dilakukan sebelum diberikan perlakuan dengan menggunakan metode pembelajaran edutainment (Hamid, 2011). Rata-rata nilai yang diperoleh siswa masih berada di bawah KKM. Siklus pertama diperoleh rata-rata nilai sebesar 34,8, siklus kedua diperoeleh nilai sebesar 46,6, dan siklus ketiga diperoleh nilai sebesar 44,1.

Hasilnya menunjukkan bahwa persentase aktivitas belajar siswa pada siklus pertama sebesar $39,8 \%$. Persentase ini mengalami peningkatan dari sebelumnya, tetapi berdasarkan kriteria aktivitas belajar masih berada pada kategori sedang. Artinya 
peningkatannya masih sedikit dari yang sebelumnya. Persentase aktivitas belajar siswa pada siklus kedua adalah sebesar 65,2\%. Persentase aktivitas belajar pada siklus kedua mengalami peningkatan kembali. Peningkatan aktivitas belajar siswa pada siklus kedua berada dalam kategori tinggi. Kemudian, hasil observasi siklus ketiga menunjukkan persentase aktivitas belajar siswa sebesar 84,2\%. Aktivitas belajar pada siklus ketiga mengalami peningkatan yang cukup signifikan. Persentase ini berada dalam kategori sangat tinggi.

Kemampuan penguasaan konsep psychrometric bisa dilihat dari hasil tes akhir yang dilakukan setelah diberikan perlakuan dengan menggunakan metode pembelajaran edutainment dalam proses pembelajarannya. Rata-rata nilai yang diperoleh siswa ada yang masih di bawah KKM dan ada yang di atas KKM. Siklus pertama diperoleh rata-rata nilai sebesar 74,4, siklus kedua diperoleh rata-rata nilai sebesar 81,1, dan siklus ketiga diperoleh rata-rata nilai sebesar 85 .

Perlakuan dalam proses pembelajaran yang dilakukan guru ternyata memiliki dampak yang cukup baik. Hasil tes memperlihatkan bahwa siswa mengalami peningkatan hasil belajar. Walaupun dari sisi hasil belajar siswa ada peningkatan, tetapi kenaikan rataratanya tidak begitu besar dari setiap siklusnya. Siklus pertama siswa mengalami peningkatan rata-rata nilai sebesar 39,5. Siklus kedua siswa hanya mengalami peningkatan rata-rata nilai sebesar 34,4 . Siklus ketiga siswa mengalami peningkatan rata-rata nilai sebesar 40,8 .

\section{PEMBAHASAN}

Tes awal yang telah dilakukan diketahui bahwa rata-rata nilai siswa dibawah KKM pada setiap siklusnya, walaupun dari sisi nilai ada peningkatan. Namun, peningkatan tersebut masih belum bisa mencapai KKM. Faktor yang sangat mempengaruhinya adalah dikarenakan siswa masih kurang terlibat aktif dan belum bisa menikmati proses pembelajaran. Faktor lainnya adalah metode yang digunakan guru dalam menyampaikan materi ini masih menggunakan pendekatan pembelajaran yang berpusat pada guru. Hal ini berdampak kepada kejenuhan siswa dalam mengikuti proses pembelajaran. Dampak lainnya adalah siswa kurang mampu menguasai materi pembelajaran. Sehingga hasil belajarnya kurang memuaskan.

Peningkatan nilainya masih berada dalam kategori sedang. Diharapkan bahwa dengan menggunakan metode pembelajaran edutainment bisa meningkatkan hasil belajar 
yang tinggi. Beberapa alasana yang dapat disampaikan sampaikan diantaranya siswa masih belum bisa menikmati proses pembelajaran dengan baik. Guru masih belum terlalu menguasai kelas, dan guru masih belum optimal dalam menggunakan metode pembelajaran edutainment (Sianturi, 2014).

Kondisi awal aktivitas belajar siswa dapatkan dari hasil observasi dengan instrumen yang mencakup aspek membaca, mencatat, bertanya, menjawab, presentasi, mendengar, partisipasi, dan antusiasme. Observasi yang dilakukan untuk melihat kondisi awal ini dilakukan ketika proses pembelajaran berlangsung di kelas. Kemudian, dirumuskan permasalan-permasalan yang timbul dalam aktivitas pembelajaran.

Observasi awal ini menghasilkan beberapa masalah yang timbul dalam aktivitas belajar siswa, diantaranya adalah siswa masih belum terkondisikan dengan baik. Siswa masih belum terlibat secara aktif dalam proses pembelajaran, metode pembelajaran yang dipakai guru cenderung monoton. Sehingga, aktivitas belajar siswa masih belum optimal. Hasil awal sebelum menggunakan metode pembelajaran edutainment, persentase aktivitas belajar siswa adalah sebesar 36,3\%. Berdasarkan kriteria aktivitas belajar, persentase ini berada pada kategori sedang. Hasil ini tidak lepas dari faktor-faktor permasalahan yang timbul ketika proses pembelajaran berlangsung (Muhaemin, 2011).

Kondisi akhir aktivitas belajar siswa setelah menggunakan metode pembelajaran edutainment mengalami peningkatan yang cukup signifikan. Hasil kondisi akhir aktivitas belajar siswa diperoleh dari hasil observasi yang dilakukan menggunakan instrumen yang sama ketika melakukan observasi awal sebelum menggunakan metode pembelajaran edutainment. Metode pembelajaran edutainment ini mampu memberikan perubahan yang lebih baik terhadap hasil belajar dan aktivitas belajar siswa. Perubahan tersebut belum bisa mencapai yang terbaik, tetapi setidaknya metode ini mampu menjadi alternatif solusi dalam menangani permasalahan yang terjadi ketika proses pembelajaran berlangsung (Mufidah, 2013).

\section{KESIMPULAN}

Penerapan metode pembelajaran edutainment pada pembelajaran psychrometric dapat meningkatkan hasil belajar pada aspek kognitif dan afektif siswa. Metode ini juga dapat meningkatkan aktivitas belajar siswa. Hal ini terlihat dari hasil penilaian yang telah dilakukan pada siswa. Penelitian ini membuktikan bahwa metode pembelajaran edutainment adalah salah satu metode pembelajaran yang mampu menjadi pemecah masalah dalam proses pembelajaran. 


\section{REFERENSI}

Dimyati, dan Mudjiono. (2006). Belajar dan Pembelajaran. Jakarta: PT. Rineka Cipta.

Hamid, M. S. (2011). Metode Edutainment. Jogjakarta: Diva Press.

Hanafiah, N. dan Suhana, C. (2009). Konsep Strategi Pembelajaran. Bandung: PT Refika Aditama.

Mufidah, L. (2013). Pengaruh Metode Edutainment terhadap Peningkatan Hasil Belajar Siswa Pada Materi Teknik-Teknik Dasar Memasak di SMK Negeri 2 Godean. Eprint UNY. 1-5.

Muhaemin. (2011). Pengaruh Penggunaan Metode Fun Teaching Terhadap Hasil Belajar Matematika. Repository UIN Jakarta.

Sianturi, R. A. (2014). Penerapan Metode Edutainment dalam Pembelajaran Menulis Teks Berita. Bahtera Bahasa: Antologi Pendidikan Bahasa dan Sastra Indonesia. 2, 1-9. 